\title{
Name correction
}

In a recent $\mathrm{CUAJ}$ article, ${ }^{1}$ the correct name of the first author is Jae Heon Kim.

Cite as: Can Urol Assoc J 2015;9(1-2):E55. http://dx.doi.org/10.5489/cuaj.2666 Published online January 12, 2015.

\section{Reference}

1. Kim JH, Yang WJ, Kim TH. Klebsiella pneumonia-induced prostate abscess: How to work it up? Can Urol Assoc J 2014;8:e841-4. http://dx.doi.org/10.5489/cuaj.2155 